\title{
Effect of secondary phases on nanostructuring and hardness of severely deformed high-strength aluminum alloy
}

\author{
M. V. Markushev ${ }^{1, \dagger}$, Yu. L. Burdastykh ${ }^{1,2}$, S. V. Krymskiy ${ }^{1}$, O. Sh. Sitdikov ${ }^{1}$ \\ †mvmark@imsp.ru \\ ${ }^{1}$ Institute for Metals Superplasticity Problems RAS, 39 Khalturin St., 450001, Ufa, Russia \\ ${ }^{2}$ Ufa State Aviation Technical University, 12 K. Marx St., 450000, Ufa, Russia
}

\begin{abstract}
Influence of precipitates, formed upon preliminary heat treatment, on the development of a nanocrystalline (NC) structure and hardness of high-strength aluminum alloy with $\mathrm{Zr}$ and Sc additions under severe plastic deformation was studied. The samples cut from homogenized ingot were processed by high-pressure torsion (HPT) via 10 revolutions under pressure $6 \mathrm{GPa}$ at room temperature. Prior to HPT, the alloy was solution treated, water quenched and annealed for 5 hours in the temperature range of $170-250^{\circ} \mathrm{C}$ to vary structural heterogeneity via changing the sizes and densities of precipitates. In addition to coherent disk-shape aluminides of transition metals about $25 \mathrm{~nm}$ in diameter (so-called dispersoids) in pre-quenched alloy, further annealing led to precipitation of the main strengthening $\eta$-type $(\mathrm{MgZn})$ phases with equivalent diameter from 10 to $200 \mathrm{~nm}$. The most developed NC structure with a (sub)grain size near $80 \mathrm{~nm}$ was processed in the pre-quenched alloy and resulted in its abnormally high hardness. HPT of the alloy pre-annealed at $170^{\circ} \mathrm{C}$ which contained $\eta$-phase precipitates of lesser size and an order of magnitude higher densities than that of dispersoids, on the contrary, produced a completely non-recrystallized structure with an up to $15 \%$ reduction in hardness owing to the suppression of grain refinement. Increasing the temperature of annealing led to coarsening and reduction in density of $\eta$-phases, intensifying the recrystallization. However, all pre-annealed NC states demonstrated even less hardness as their work hardening could only partially compensate the alloy softening due to $\eta$-phase coagulation.
\end{abstract}

Keywords: aluminum alloy, high-pressure torsion, precipitates, nanostructuring, recrystallization.

\section{Влияние вторичных фаз на наноструктурирование и твердость интенсивно деформированного высокопрочного алюминиевого сплава}

\author{
Маркушев М. В. ${ }^{1, \dagger}$, Бурдастых Ю. Л. ${ }^{1,2}$, Крымский С. В. ${ }^{1}$, О. Ш. Ситдиков ${ }^{1}$ \\ ${ }^{1}$ Институт проблем сверхпластичности металлов РАН, ул. Ст. Халтурина 39, 450001, Уфа, Россия \\ ${ }^{2}$ Уфимский государственный авиационный технический университет, ул. К. Маркса 12, 450000, Уфа, Россия
}

Исследовано влияние выделений вторичных фаз, сформированных предварительной термообработкой, на формирование при интенсивной пластической деформации нанокристаллической (НК) структуры и твердость высокопрочного алюминиевого сплава с добавками Zr и Sc. Образцы, вырезанные из гомогенизированного слитка, были подвергнуты кручению под высоким давлением (КВД) (10 оборотов при давлении 6 ГПа) при комнатной температуре. Предварительно сплав закаливали в воду и отжигали в течение 5 часов в интервале температур $170-250^{\circ} \mathrm{C}$ для придания разной степени гетерогенности структуры путем изменения размеров и плотности вторичных выделений. В дополнение к когерентным алюминидам переходных металлов в форме диска диаметром около 25 нм (так называемым дисперсоидам) в предварительно закаленном сплаве, при отжиге формировались выделения основных упрочняющих фаз $\eta$ типа (MgZn) с эквивалентным диаметром от 10 до 200 нм. Наиболее развитая НК структура с размером (суб)зерна около 80 нм формировалась при КВД закаленного сплава, придавая ему аномально высокую твердость. КВД предварительно отожженного при $170^{\circ} \mathrm{C}$ сплава с выделениями $\eta$-фаз меньшего размера и на порядок большей плотности, чем дисперсоиды, напротив, приводило к подавлению измельчения зерен и полностью нерекристаллизованной структуре с примерно на 15\% меньшей твердостью. С увеличением температуры отжига выделения $\eta$-фаз огрублялись и уменьшалось их количество, интенсифицируя рекристаллизацию. Однако все отожженные НК состояния демонстрировали меньшую твердость, так как структурное (деформационное) упрочнение сплава лишь частично компенсировало его разупрочнение, вызванное коагуляцией $\eta$-фаз.

Ключевые слова: алюминиевый сплав, кручение под высоким давлением, выделения, наноструктурирование, рекристаллизация. 


\section{Introduction}

Despite a huge number of data published on the effect of severe plastic deformation (SPD) on structure, phase composition and mechanical behavior of metallic materials (for example, in reviews [1-4]), it should be noted that the mechanisms, as well as the main structural factors responsible for their hardening, are still not so clear. For instance, the role of precipitates in the development of the structure and properties of the alloys with matrix type microstructure, to which the overwhelming majority of wrought aluminum alloys belongs, strongly required detailed specification. The least clear situation is with complex age-hardenable alloys having two types of precipitates, namely, aluminides of transition metals (so-called dispersoids) and main strengthening phases. In spite of the fact that the both precipitates are the products of the aluminum solid solution decomposition, their origin is different. The dispersoids are formed under homogenization and hot deformation of an ingot with initial aluminum solid solution supersaturated by transition metals. The other phases appear at strengthening/softening heat treatment, that is, at aging/heterogenization annealing of a pre-quenched (solid solution treated) ingot or wrought semi-product at temperatures below their solvus points.

So, the present work is aimed to evaluate the effect of the main strengthening phases and their parameters on the deformation nanostructuring and hardness of the complexalloyed high-strength aluminum alloy.

\section{Material and procedure}

The $20 \mathrm{~mm}$ in diameter and $1.2 \mathrm{~mm}$ in thickness samples, cut out from the homogenized ingot with a nominal alloy composition of $\mathrm{Al}-8 \mathrm{Zn}-2 \mathrm{Mg}-2 \mathrm{Cu}-0.3 \mathrm{Sc}-0.1 \mathrm{Zr}-0.1 \mathrm{Mn}$, were quenched in water from a temperature of $460^{\circ} \mathrm{C}$. Part of them was further annealed for 5 hours in the temperature range of $170-250^{\circ} \mathrm{C}$ to give different structural heterogeneity. All samples were then subjected to high pressure torsion (HPT) with 10 revolutions under the pressure of $6 \mathrm{GPa}$ at room temperature.

The structure analysis was carried out using JEOL 2000EX transmission electron microscope (TEM). Objects for analysis were prepared by jet-electropolishing at a current of $20 \mathrm{~V}$ and temperature of $-28^{\circ} \mathrm{C}$ on the Tenupol 5 device in a solution of $750 \mathrm{ml} \mathrm{CH}_{3} \mathrm{OH}$ and $250 \mathrm{ml} \mathrm{HNO}_{3}$. The sizes and densities of precipitates were measured with an error less than $20 \%$ using computer image analysis (see more details in [5]). Density of particles was measured in areas having close thickness of foils.

Microhardness before and after SPD was determined using Axiovert optical microscope at the load of $1 \mathrm{~N}$ and duration of $15 \mathrm{sec}$. For the deformed samples it was measured near the middle of the radius.

\section{Results and discussions}

TEM analysis have shown that the as-quenched alloy has a unimodal size distribution of precipitates consisting of diskshape coherent $\mathrm{Al}_{3}(\mathrm{Zr}, \mathrm{Sc})$ phases (Fig. 1a) and having an average diameter of about $20 \pm 2 \mathrm{~nm}$ and density of $3 \times 10^{3} \mu^{-3}$. In the as-annealed at $170^{\circ} \mathrm{C}$ (pre-aged) alloy (Fig. 1b) precipitate size distribution became a bimodal one due to an addition of the main strengthening $\eta$-type (MgZn) phases of nearly twice less size $(8 \mathrm{~nm})$ and an order of magnitude higher density $\left(4 \times 10^{4} \mu^{-3}\right)$. After annealing at $200^{\circ} \mathrm{C}$, resulting in some coarsening of $\eta$-type phases, the distribution was found to be again unimodal with more than doubled amount of precipitates of $20 \mathrm{~nm}$ modal size. Further increase in the annealing temperature brings back the precipitate size bimodality. However, it has another origin, as the second mode was formed by coarse (up to $200 \mathrm{~nm}$ ) and stable $\eta$-phases of twice less densities than of dispersoids (Fig. 1d).

The evolution of alloy's microhardness under preliminary heat treatment is shown in Table 1. These data are common for age-hardenable alloys and testify its conventional aging and overaging response. That is, the maximum hardness before SPD was found in the pre-aged state having more disperse phases of the highest densities.

Coagulation of $\eta$-phases under annealing at 200 and $250^{\circ} \mathrm{C}$ resulted in the alloy overaging with precipitate size increase and decrease in their density, leading to the hardness drop up to the level of as-quenched, solution hardened state.

TEM analysis has demonstrated a well-developed nanocrystalline $(\mathrm{NC})$ structure of an aluminum matrix with

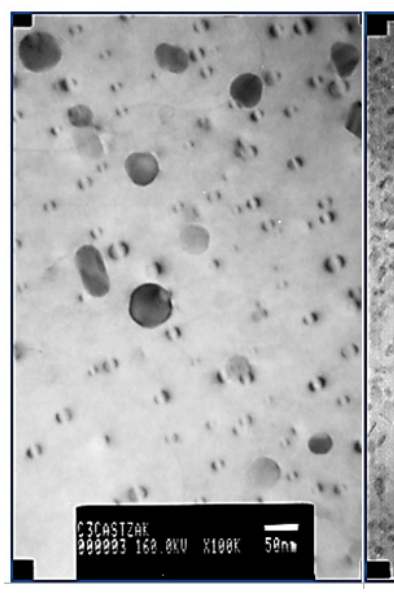

a

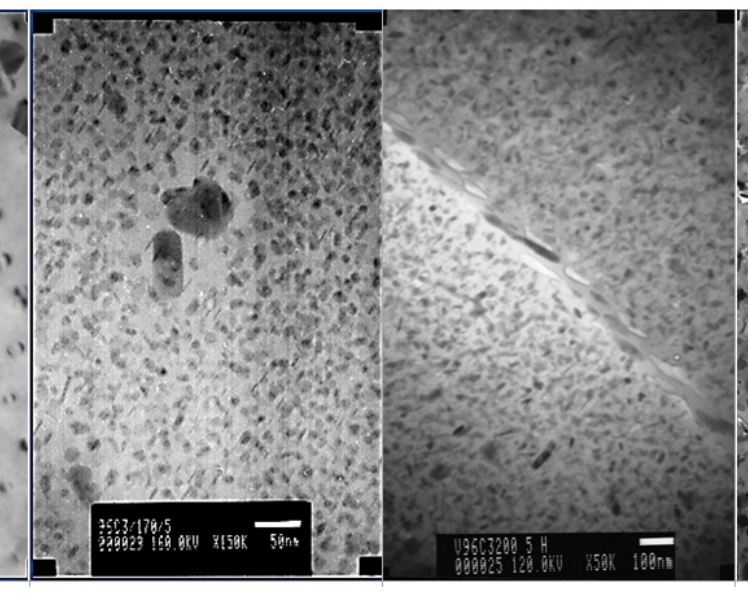

$\mathrm{b}$

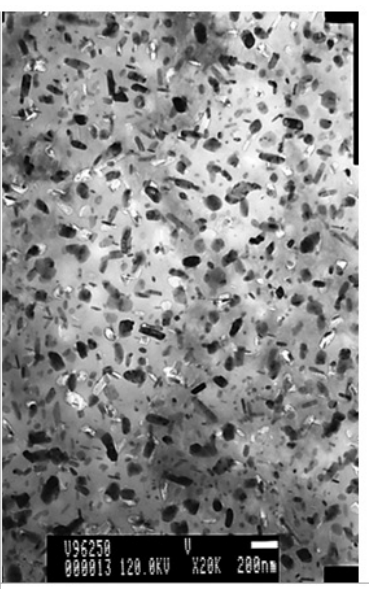

d

Fig. 1. Distribution of precipitates in the alloy after quenching (a) and further 5 hrs annealing at 170 (b), 200 (c) and $250^{\circ} \mathrm{C}$ (d). The coherent and semi-coherent disc-shape $\mathrm{Al}_{3}(\mathrm{Zr}, \mathrm{Sc})$ phases are visible in $(\mathrm{a}),(\mathrm{b}-\mathrm{d})$ illustrate $\eta$-type phases of different composition, shape, size and density. 
an average size of nearly equiaxed (sub)grains of $80 \mathrm{~nm}$ formed under SPD in as-quenched alloy (Fig. 2a and 2b). Virtually, the main mechanism of structure transformations was continuous dynamic recrystallization. On the opposite, the structure in the pre-aged at $170^{\circ} \mathrm{C}$ condition was highly work-hardened with high densities of homogeneously distributed dislocations and their pile-ups (Fig. 2c and 2d). So, even few hours of preliminary aging, resulting in an order of magnitude increase in the density of nanosized precipitates, led to a strong suppression of nanostructuring of the matrix caused by any dynamic processes of fragmentation, polygonization or recrystallization [6]. This can be evident from bright field images and also from selected area electron diffraction patterns. Such an alloy behavior is related to an increase in the density of precipitates of $10-20 \mathrm{~nm}$ size, resulting in increased homogeneity of plastic flow and in suppression of dislocation rearrangements with a consecutive formation of deformation bands, cells, subgrains and, finally, grains under SPD [1, 7-9].

Such a sequence of processes of the structure formation has occurred under HPT in the samples pre-annealed at higher temperatures (Fig. $2 \mathrm{e}-2 \mathrm{~h}$ ). However, the $\mathrm{NC}$ structures processed were characterized by a non-equiaxed shape of crystallites and their somewhat larger size, than in the pre-quenched material. It should be noted that both equiaxed and elongated nanostructures had been also observed in aluminum alloys subjected to other SPD techniques based on shear straining [7-11]. Their features can be associated with the development of a spatial net of microshear bands oriented in various directions and intersecting the elongated cellular substructures with high densities of lattice dislocations. Shearing by microshear bands leads to an apparent bending of the cell and microshear bands evolved by SPD, resulting in a wavy substructure.

It should be also noted that after SPD via «cold» HPT both types of secondary phases were TEM detectable (Fig. 2) testifying the absence of their complete dissolution frequently observed under SPD $[3,4]$. Moreover, relying upon the deltazero contrast, many of dispersoids still remained coherent, meaning no changes in their orientation regarding the surrounding aluminum lattice.

Table 1. The alloy hardness before and after high-pressure torsion in different initial conditions.

\begin{tabular}{ccccc}
\hline \multirow{3}{*}{ Condition } & \multicolumn{4}{c}{ Hardness, HV } \\
\cline { 2 - 5 } & Pre-quenched & \multicolumn{3}{c}{ Annealed at, ${ }^{\circ} \mathrm{C}$} \\
\cline { 2 - 5 } & & 170 & 200 & 250 \\
\hline Before HPT & $110 \pm 10$ & $160 \pm 15$ & $120 \pm 10$ & $80 \pm 10$ \\
After HPT & $270 \pm 10$ & $235 \pm 15$ & $225 \pm 12$ & $220 \pm 10$ \\
\hline
\end{tabular}

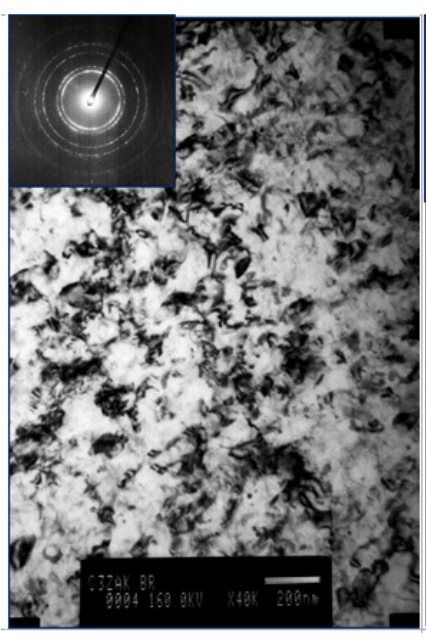

a

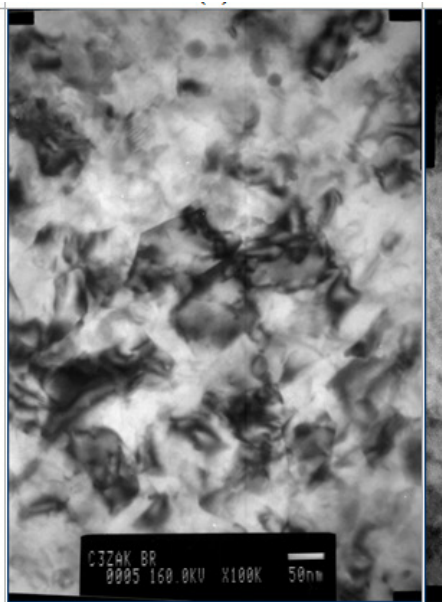

b
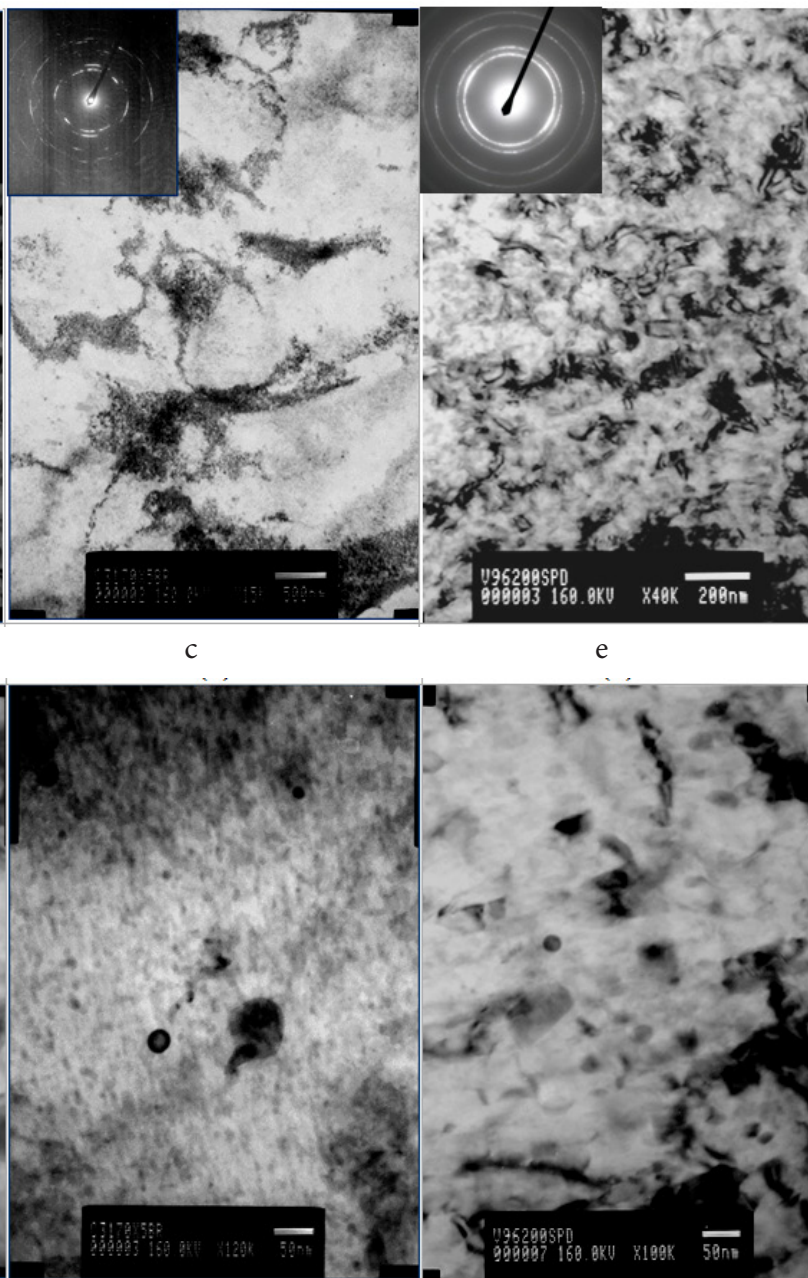

d

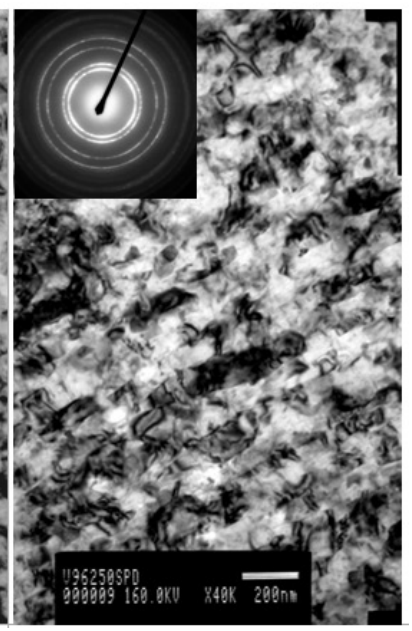

g

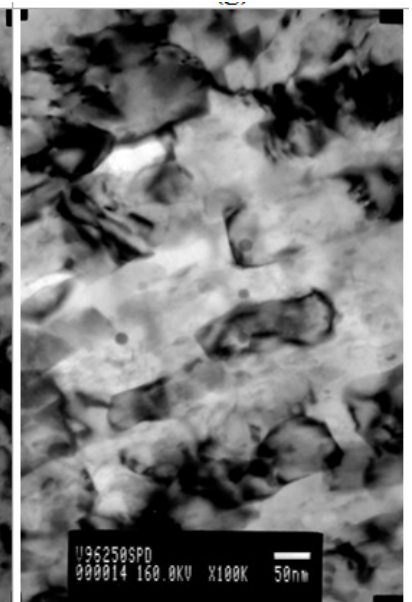

$\mathrm{h}$

Fig. 2. TEM structures of severely deformed alloy in preliminarily quenched (a and b) and annealed during 5 hrs at 170 (c and d), 200 (e and $\mathrm{f}$ ) and $250^{\circ} \mathrm{C}$ (g and $\mathrm{h}$ ) conditions. 
Despite the low temperature deformation to high strains and high structure defectiveness of all HPT samples studied, the initial alloy condition significantly affected their hardness (Table 1). The level of hardness found in the NC pre-quenched alloy was abnormally high for conventionally processed products, but comparable with the one exhibited by other Al alloys after SPD using similar method and carried out to similar strains $[3,4]$. Meanwhile, the alloy in the preannealed conditions showed a considerably lower hardness with the values being in a good agreement with the type of the structure processed and degree of its initial heterogeneity. Suppression of the alloy nanostructuring because of aging with precipitation of disperse phases of high densities (or because of dispersion strengthening close to its maximum) leads to the material minimum work- (strain-) and structural hardening, and reaching the hardness level typical for substructure- and disperse-strengthened commercial semiproducts. Activation of recrystallization with increasing the size of precipitates and decreasing their density with rise in the annealing temperature resulted in further hardness stabilization. This means that strengthening due to the nanostructuring of the matrix cannot completely compensate the drop in the alloy's strength owing to the loss in dispersion hardening.

Hardness of the initially homogenized and quenched alloy was conditioned by three main factors: i) strength of pure aluminum (Peierls-Nabarro force), ii) aluminum solution hardening due to the supersaturation by main alloying elements $(\mathrm{Zn}, \mathrm{Mg}, \mathrm{Cu})$ and iii) matrix dispersion strengthening by aluminides of transition metals. These three contributions gave the hardness of about $110 \mathrm{HV}$ (Table 1). Further $5 \mathrm{hrs}$ aging at $170^{\circ} \mathrm{C}$ owing to $\eta$-phase dispersion hardening increased it up to $160 \mathrm{HV}$, i.e. on $50 \mathrm{HV}$ (in fact the effect of dispersion hardening is higher, because it partially compensates the decreased solid solution strengthening). Under HPT the pre-quenched alloy possesses work- and grain boundary strengthening with a total amount of $160 \mathrm{HV}$, giving the hardness of $270 \mathrm{HV}$. The first effect is mainly conditioned by an increase in dislocation density and the second one - by grain and subgrain refinement, being the maximum in this state. Meanwhile, realization of these both effects in the initially overaged states with minimum solution and $\eta$-phase dispersion strengthening led to hardness of about $220 \mathrm{HV}$. So, the comparison of the hardness levels obtained gives an easy estimation that the "pure» effect on the formation of nanoscale network of (sub)grain boundaries in the alloy matrix is about $80 \mathrm{HV}$ and its contribution is equal to work hardening under HPT, as even close to the alloy dispersion strengthening.

Thus, it could be concluded, that the cold HPT can provide the alloy extra hardening due to the formation of a nanostructure and increase in dislocation density, exceeding the conventional dispersion strengthening by a factor of almost two. An effective combination and implementation of these three strengthening mechanisms in one processing route are still quite complex task having a considerable potential for age-hardenable alloys. For that purpose, by analogy with known processing of fine-grained products [12], it is necessary to develop the principles of optimization of structure heterogeneity for treatment routes involving severe straining. The task should give and prove the methods of control of these principles, and should demand modified specification and number of their parameters, taking into account the nature of deformation nanostructuring, efficiency and potential of its further industrial applications.

\section{Conclusions}

1. On an example of high-strength $7 \mathrm{xxx}$ alloy, it has been shown that when doing thermomechanical treatment of age-hardenable aluminum alloys, aiming to impart them nanocrystalline structure and to control their strength, one necessarily has to consider parameters of heterogeneity of their initial structure. Maximum grain refinement and alloy strengthening were observed under SPD realized by cold HPT of the preliminarily solution treated and quenched alloy. Pre- aging can completely suppress the alloy matrix nanostructuring, and pre-overaging activates it, however, with a simultaneous considerable drop in strength.

2. Analysis of the role of various factors, affecting the alloy strengthening allows concluding that an extra hardening, due to SPD can reach the values of about $160 \mathrm{HV}$. The direct contribution into the alloy hardness due to formation of nanoscale network of (sub)grain boundaries does not exceed $80 \mathrm{HV}$. It is comparable with the effect on work hardening owing to increasing the dislocation density under SPD, and a bit higher than the alloy dispersion strengthening under the studied heat treatment conditions.

Acknowledgments. The authors acknowledge funding from the Russian Science Foundation under the grant № 16-19-10152.

\section{References}

1. F. J. Humphreys, P. B. Prangnell, J. R. Bowen, A. Gholinia, C. Harris. Phil. Trans. R. Soc. Lond. A357, 1663 (1999).

2. R.Z. Valiev, T.G. Langdon. Prog. Mater. Sci. 51, 881 (2006).

3. R.Z. Valiev, I.V. Aleksandrov, Bulk Nanostructured Metallic Materials: Processing, Structure, and Properties, - Moscow: Akademkniga. 2007 [in Russian].

4. R.Z. Valiev, Y. Estrin, Z. Horita, T.G. Langdon, M. J. Zehetbauer, Y. T. Zhu. Mater. Res. Lett., 4, 1 (2016).

5. D. R. Nugmanov, O.Sh. Sitdikov, M. V. Markushev, Lett. Mat. 4, 209 (2014). (in Russian)

6. F.J. Humphreys, M. Hatherly. Recrystallization and Related Annealing Phenomena, 2nd ed. - Amsterdam: Elsevier. 2004. 658 p.

7. O. Sitdikov, S. Krymskiy, M. Markushev, E. Avtokratova, T. Sakai. Rev. Adv. Mater. Sci. 31 (2012) 62-67.

8. P. J. Apps, M. Berta, P. B. Prangnell. Acta Mater. 53 (2005) $499-511$.

9. M.Kh. Rabinovich, M.V. Markushev, J. Mat. Sci. 31 (1996) $4997-5001$.

10. R.Z. Valiev, A.V. Korznikov, R.R. Mulyukov, Mat. Sci. Eng.: A. 168 (1993) $141-148$.

11. M. V. Markushev, Phys. Met. Metallogr. 8 (2009) $161-170$.

12. M. V. Markushev, Phys. Met. Metallogr. 7 (2009) 43 - 49. 